\title{
PERLUASAN MAKNA HARTA BERSAMA PERSPEKTIF SOSIOLOGI HUKUM ISLAM
}

\author{
Isnadul Hamdi \\ Jurusan Syariah STAI Solok Nan Indah, \\ Jl. Adinegoro No. 59 BY Pass KTK Kota Solok \\ e-mail: Isnadul_Hamdi@yahoo.com
}

\begin{abstract}
This research is based on the problems in the distribution of common property. First, the emerging of differences in the system of distributing of common property in talak raj'i and talak ba'in. Second, the occurrence of expansion in terms of income during marriage such as the existence of insurance. Third, the existence of the agreement in marriage before the joint property is shared. The result of the research shows that in the sociology perspective of Islamic law the effort to share the common property: first, in the case of divorce because the situation is still in the iddah period of talak raj'i, property should not be divided because it minimizes the possibility of reunification. Unlike the case if talak ba'in, property should be devidedd soon because it certainly will not be reunited. Second, in response to the expansion of common property such as the existence of insurance money, all Indonesian Judge agreed that all property acquired during marriage is related to Taspen Insurance, Asabri Fund, Labor Insurance, Traffic Accident Fund, Passenger Accident Fund, Life Insurance Fund, Property of Luggage, Credit that has not paid off. Third, the agreement in marriage greatly affects the distribution of common property given the existence of Article 45, 52, and 97 Compilation of Islamic Law "divorced or divorced widow respectively entitled to two joint property as long as not specified in the marriage agreement.
\end{abstract}

Kata kunci: harta bersama, Sosiologi Hukum Islam

\section{PENDAHULUAN}

Seseorang yang telah melangsungkan Sperkawinan tidak akan bisa terlepas dari pembauran atau percampuran harta. Harta dalam perkawinan termasuk salah satu hal yang penting sebab tanpa harta sulit sekali bagi pasangan untuk mewujudkan tujuan perkawinan yaitu terciptanya ketentraman, cinta dan kasih sayang (sakinah, mawaddah warahmah). Di sisi lain, terjadinya percampuran harta selama dalam perkawinan bisa menimbulkan persoalan ketika telah terjadi perceraian (talak), baik itu talak raj'i atau talak ba'in.

Dalam hal terjadinya peristiwa talak raj'i dan talak ba'in, para ulama berbeda pendapat dalam menyikapi bagaimana teknis pembagian harta bersama apakah disamakan cara pembagiannya atau dibedakan. Jika pasangan suami isteri pernah mencoba untuk ikut serta dalam hal uang asuransi seperti asuransi jiwa atau mendapatkan asuransi karena kecelakaan penumpang, maka harta tersebut juga mengundang perhatian oleh para pakar hukum di bidangnya. 
Problematika tentang pembagian harta bersama biasanya jarang muncul jika sejak awal telah diadakan semacam kesepakatan-kesepakatan seperti membuat perjanjian dalam perkawinan. Namun, jika tidak ada perjanjian dalam perkawinan, maka persoalan tentang permbagian harta bersama tetap harus diselesaikan sesuai dengan aturan hukum yang berlaku, baik itu berdasarkan Peraturan Perundang-undangan, KHI, dan Pendapat ulama fiqh.

\section{METODE PENELITIAN}

Penelitian ini bercorak penelitian kepustakaan (library research), dengan mengumpulkan, membaca, dan menelaah buku-buku yang ada kaitannya dengan pembahasan ini. Sumber primer berupa Al-Qur'an, Hadis dan Pendapat para ulama, Perundang-undangan. Sedangkan Sumber sekunder berupa karya-karya yang berhubungan dengan bahasan ini, bisa berupa artikel dan sumber informasi lainnya yang sifatnya menambah khazanah pemahaman tentang perluasan harta bersama dalam perspektif sosiologi hukum Islam.

\section{TINJAUAN PENELITIAN YANG RELEVAN}

Penelitian terdahulu yang relevan dengan penelitian ini, di antaranya: Abdul Basith Junaidy yang meneliti tentang Harta Bersama dalam Hukum Islam di Indonesia (Perspektif Sosiologis) Jurnal AlQanun, Vol. 17, No. 2, Desember 2014. Hasil penelitiannya mengungkapkan bahwa harta bersama dalam keluarga merupakan institusi yang berakar dari budaya dan berurat sosial di dalam kelompok masyarakat Islam tertentu. Tinjauan hukum mengenai harta bersama harus selalu menyertakan kajian terhadap adat kebiasaan yang hidup di masyarakat, khususnya mengenai posisi perempuan dalam rumah tangga.

Adapun penelitian yang penulis lakukan ini mendeskripsikan kembali contoh-contoh perubahan disebabkan oleh alasan sosiologis tentang harta bersama.

\section{SOSIOLOGI HUKUM ISLAM}

Sosiologi Hukum Islam terdiri dari dua kata, Sosiologi dan Hukum Islam. Menurut Max Weber yang dimaksud dengan sosiologi adalah ilmu yang berupaya memahami tindakan-tindakan sosial (Yesmil Anwar dan Adang : 2008).

Adapun Hukum Islam menurut Amir Syarifuddin sebagaimana dikutip oleh Fathurrahman Djamil berarti seperangkat peraturan berdasarkan wahyu Allah dan Sunnah Rasul tentang tingkah laku manusia mukallaf yang diakui dan diyakini berlaku dan mengikat untuk semua umat yang beragama Islam. (Fathurrahman Djamil: 2013).

Hukum Islam merupakan fenomena budaya dan fenomena sosial sekaligus. Agama dianggap sebagai femonena budaya, karena agama adalah kepercayaan sedangkan interaksi antara sesama pemeluk agama adalah gejala sosial. (M. Rasyid Ridla: 2012).

Jadi Sosiologi Hukum Islam menurut hemat penulis berarti suatu ilmu yang berupaya memahami seperangkat peraturan berdasarkan wahyu Allah dan Sunnah Rasul serta tindakan-tindakan sosial. 
Setiap memperhatikan tindakantindakan sosial itu haruslah mengacu kepada prinsip-prinsip hukum Islam. Ada beberapa prinsip-prinsip hukum Islam (Fathurrahman Djamil: 2013), di antara nya:

1. Meniadakan Kesulitan dan Tidak Memberatkan

2. Menyedikitkan Beban

3. Memperhatikan kemaslahatan manusia Hubungan sesama manusia merupakan manifestasi dari hubungan dengan pencipta. Apabila baik hubungan dengan manusia lain maka baik pula hubungan dengan penciptanya. Oleh karena itu, hukum Islam sangat menenakankan kemanusiaan. Ayat-ayat yang berhubungan dengan penetapan hukum tidak pernah meninggalkan masyarakat sebagai bahan pertimbangan.

4. Mewujudkan Keadilan yang Merata

Menurut syari'at Islam, semua manusia sama. Tidak ada kelebihan seorang manusia dari yang lain dihadapan hukum. Penguasa tidak terlindung oleh kekuasaannya ketika ia berbuat kezaliman. Orang kaya dan orang berpangkat tidak terlindung oleh harta dan pangkat ketika yang bersangkutan berhadapan dengan pengadilan Allah.

\section{HARTA BERSAMA DAN PERLUASAN MAKNANYA \\ Pengertian Harta Bersama}

Menurut Ter Haar, Harta bersama bermakna barang-barang yang diperoleh suami istri selama perkawinan. (Ismail Muhammad Syah: 1978).

Konsep harta bersama mengalami perluasan makna seiring dengan perkembangan sosial yang terjadi di tengah masyarakat.

\section{Harta Bersama Menurut Hukum Islam}

Bila mengacu kepada sumber rujukan Hukum Islam baik dalam AlQur'an, sunnah tidaklah ditemukan aturan yang secara jelas mengatur tentang persoalan harta bersama. Akan tetapi, jika dikaitkan harta bersama itu dengan konteks syirkah, maka secara tersirat dapatlah dipahami bahwa salah satu di antara ayat yang dapat dijadikan sumber tentang harta bersama yaitu Al-Qur'an surat an-Nisa' ayat 32 di mana dikemukakan bahwa bagian dari apa yang mereka usahakan dan semua wanita ada bagian dari apa yang mereka usahakan pula.

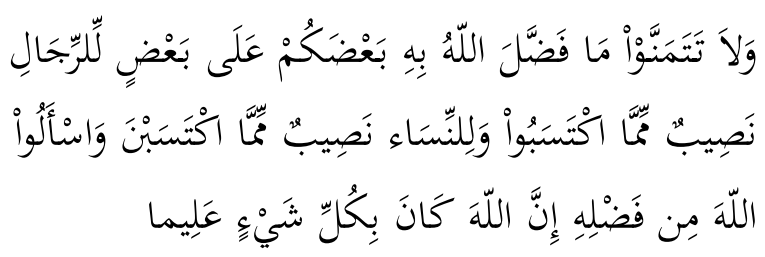

"Dan janganlah kamu iri hati terhadap karunia yang telah Dilebihkan Allah kepada sebagian kamu atas sebagian yang lain. (Karena) bagi laki-laki ada bagian dari apa yang mereka usahakan, dan bagi perempuan (pun) ada bagian dari apa yang mereka usahakan. Mohonlah kepada Allah sebagian dari karunia-Nya. Sungguh, Allah Maha Mengetahui segala sesuatu."(Q.S. AnNisa [4]: 32). 
Adapun ijtihad 'ulama dalam memahami makna harta bersama, kebanyakan ulama fiqh mengaitkannya dengan syarikat, seperti di kalangan mazhab Syafi'i terdapat empat macam yang disebutkan harta syarikat, di antaranya yaitu:

1. Syarikat 'inan, yaitu dua orang yang berkongsi di dalam harta tertentu, misalnya bersyarikat di dalam membeli suatu barang dan keuntungannya untuk mereka.

2. Syarikat abdan, yaitu dua orang atau lebih bersyarikat masing-masing mengerjakan suatu pekerjaan dengan tenaga dan hasilnya (upahnya) untuk mereka bersama menurut perjanjian yang mereka buat, seperti tukang kayu, tukang batu, mencari ikan di laut, berburu dan kegiatan yang seperti menghasilkan lainnya.

3. Syarikat Muwaffadlah, yaitu perserikatan dua orang atau lebih untuk melaksanakan suatu pekerjaan dengan tenaganya yang masing-masing di antara mereka mengeluarkan tenaganya yang masing-masing di antara mereka mengeluarkan modal, menerima keuntungan dengan tenaga dan modalnya, masingmasing melakukan tindakan meskipun tidak diketahui oleh pihak lain.

4. Syarikat wujuh, yaitu syarikat atas tanpa pekerjaan ataupun harta yaitu permodalan dengan dasar kepercayaan pihak lain kepada mereka (Abdul Hanan, 2008: 110).
Terhadap pembagian harta syarikat sebagaimana tersebut di atas, hanya syarikat 'inan yang disepakati oleh semua pakar hukum Islam, sedangkan tiga syarikat lainnya masih diperselisihkan keabsahannya. Meskipun pembagian syarikat seperti yang telah dikemukakan dibagi empat oleh para ahli hukum Islam di kalangan mazhab Syafi'i, tetapi dalam praktek peradilan mereka hanya mengakui syarikat 'inan saja. Para pakar hukum Islam di kalangan mazhab Hanafi dan Maliki dapat menerima syarikat ini karena syarikat tersebut merupakan mu'amalah yang harus dilaksanakan oleh setiap orang dalam rangka mempertahankan hidupnya.

Syarikat itu dapat dilaksanakan asalkan tidak dengan paksaan, dan dilaksanakan dengan i'tikad yang baik. Jika salah satu pihak merasa tidak cocok lagi melaksanakan perkongsian yang disepakati, maka ia dapat membubarkan perkongsian itu secara baik dan terhadap hal ini tidak dapat diwariskan.

Masalah pencarian bersama suami istri jelas termasuk perkongsian atau syirkah, maka untuk mengetahui hukumnya perlu melakukan pendekatan lebih dahulu tentang macam-macam perkongsian sebagaimana telah dibicarakan oleh para ulama dalam kitab fikih. Harta bersama dalam perkawinan itu digolongkan dalam bentuk syarikat abdan dan muwaffadlah. Suatu hal yang penting untuk dicatat bahwa doktrin hukum fikih tidak ada yang membahas 
secara rinci tentang masalah harta bersama suami istri dalam perkawinan.

Dalam Kompilasi Hukum Islam (KHI), terjadi perluasan makna tentang harta bersama. Hal ini sebagaimana terdapat dalam pasal-pasal berikut ini:

\section{Pasal 85}

Adanya harta bersama dalam perkawinan itu tidak menutup kemungkinan adanya harta milik masing-masing suami atau istri.

\section{Pasal 86}

1. Pada dasarnya tidak ada percampuran antara harta suami dan harta istri karena perkawinan.

2. Harta istri tetap menjadi hak istri dan dikuasai penuh olehnya, demikian juga harta suami tetap menjadi hak suami dan dikuasai penuh olehnya.

\section{Pasal 87}

1. Harta bawaan dari masing-masing sebagai hadiah atau warisan adalah dibawah pengusaan masing-masing sepanjang para pihak tidak menentukan lain dalam perjanjian perkawinan.

2. Suami dan istri mempunyai hak sepenuhnya untuk melakukan perbuatan hukum atas harta masingmasing berupa hibah, hadiah, Shodaqah, atau lainnya.

$$
\text { Pasal } 88
$$

Apabila terjadi perselisihan antara suami istri tentang harta bersama, maka penyelesaian perselisihan itu diajukan kepada Pengadilan Agama

\section{Pasal 89}

Suami bertanggungjawab menjaga harta bersama maupun harta suami yang ada padanya.
Pasal 90

Istri turut bertanggung jawab menjaga harta bersama, maupun harta suami yang ada padanya.

\section{Pasal 91}

1. Harta bersama sebagaimana tersebut dalam pasal 85 di atas dapat benda berwujud atau tidak berwujud.

2. Harta bersama yang berwujud dapat meliputi benda tidak bergerak, benda bergerak dan surat-surat berharga.

3. Harta bersama yang tidak berwujud dapat berupa hak maupun kewajiban.

4. Harta bersama dapat dijadikan sebagai barang jaminan dan salah satu pihak atas persetujuan pihak lainnya.

Pasal 91 KHI di atas dapat di pahami bahwa adanya perbedaan kehidupan sosial zaman Nabi Muhammad dengan kondisi sosial saat ini, saat ditemukan harta yang berupa surat-surat berharga, saham, cek, dan lain-lain. Maka, pengertian harta kekayaan menjadi luas jangkauannya. Sebab, tidak hanya barang-barang materil yang langsung menjadi bahan makanan, malainkan termasuk non materil berupa jasa dan sebagainya. Yang penting adalah pengunaan kekayaan dimaksud, baik kepentingan salah satu pihak maupun kepentingan bersama harus selalu berdasarkan musyawarah sehingah akan tercapai tujuan perkawinan.

\section{Pasal 92}

Suami atau istri tanpa persetujuan pihak lain, tidak diperbolehkan menjual atau memindahkan harta bersama. 


\section{Pasal 93}

1. Pertangggungjawaban terhadap hutang suami atau istri dibebankan pada hartanya masing-masing.

2. Pertangungjawaban terhadap hutang yang dilakukan untuk kepentingan keluarga, dibebankan kepada harta bersama.

3. Bila harta bersama tidak mencukupi, dibebankan kepada harta suami.

4. Bila harta suami tidak ada atau tidak mencukupi maka dibebankan kada harta istri.

Pasal 93 tersebut seakan mengesankan adanya pemisahan antara harta suami dan istri, karena tidak ada penjelasan tentang kapan utang suami atau istri itu dilakukan, maka penafsiran yang dapat dilakukan adalah apabila utang tersebut tidak ada sangkut pautnya dengan kepentingan keluarga. Namun sebaliknya, untuk menutupi kebutuhan rumah tangga, jika harta bersama tidak mencukupi, maka di ambil dari harta pribadi masing-masing suami atau sang istri. Itupun apabila perkawinannya yang bersifat monogami yang relatif kecil peluang terjadinya, perselisihan di antara mereka di banding perkawinan poligami.

Dalam kaitan dalam perkawinan poligami, kompilasi mengaturnya dalam pasal $94 \mathrm{KHI}$ :

1. Harta bersama dari perkawinan seorang suami yang mempunyai istri lebih dari seorang, masing-masing terpisah dan berdiri sendiri.

2. Pemilikan harta bersama dari perkawinan seseorang suami yang mempunyai istri lebih dari seorang sebagaimana tersebut pada ayat 1 . Dihitung pada saat berlangsungnya akad perkawinan yang kedua, ketiga, atau keempat. $\begin{array}{ccr}\text { Ketentuan } & \text { Pasal } & 94 \\ \text { dimaksudkan agar } & \text { antara } & \text { istri }\end{array}$ petama, kedua, ketiga, ataupun keempat, tidak terjadi perselisihan. Di samping itu juga untuk mengantisipasi kemungkinan gugat warisan di antara masing-masing keluarga dari istri-istri tersebut. Akibat ketidakjelasan pemilikan harta bersama antara istri pertama dan kedua, sering menimbulkan sengketa waris yang diajukan ke pengadilan Agama. Lebih-lebih lagi apabila poligami tersebut dilakukan dengan tanpa pertimbangan tertib hukum dan administrasi, berupa pencatatan nikah, itu tentu saja menyulitkan keluarga mereka itu sendiri, boleh jadi tidak dapat dijangkau oleh hukum karena secara yuridis formal tidak ada bukti-bukti otentik, bahwa mereka telah melakukan perkawinan.

Pasal 95

1. Dengan tidak mengurangi ketentuan pasal 24 ayat (2) huruf c peraturan pemerintah nomor 9 tahun 1975 dan pasal 136 untuk meletakkan sita jaminan atas harta bersama tanpa adanya permohonan gugatan cerai, apabila salah satu melakukan perbuatan yang merugikan dan membahayakan harta bersama seperti judi, mabuk, boros, dan sebagainya.

2. Selama masa sita dapat dilakukan penjualan atas harta bersama untuk kepentingan keluarga dengan izin pengadilan agama.

\section{Pasal 96}

1. Apabila terjadi cerai mati, maka separuh harta bersama menjadi hak pasangan yang hidup lebih lama. 
2. Pembagian harta bersama bagi seorang suami atau istri yang istri atau suaminya hilang harus ditangguhkan sampai adanya kepastian matinya yang hakiki atau matinya secara hukum atas dasar keputusan pengadilan agama.

\section{Pasal 97}

Janda atau duda cerai masing-masing berhak seperdua dari harta bersama sepanjang tidak ditentukan lain dalam perjanjian dalam perkawinan.

Ketentuan hukum Islam tersebut sangat realistis, karena kenyataannya percampuran hak milik suami istri menjadi harta bersama banyak menimbulkan masalah dan kesulitan sehingga memerlukan aturan khusus untuk menyelesaikannya. Meskipun hukum Islam tidak mengenal adanya percampuran harta pribadi masing-masing ke dalam harta bersama suami istri tetapi dianjurkan adanya saling pengertian antara suami istri dalam mengelola harta pribadi tersebut, jangan sampai di dalam mengelola kekayaan pribadi ini dapat merusak hubungan suami istri yang menjurus kepada perceraian.

Apabila dikhawatirkan akan timbul hal-hal yang tidak diharapkan, maka hukum Islam memperbolehkan diadakan perjanjian perkawinan sebelum pernikahan dilaksanakan. Perjanjian itu dapat berupa penggabungan harta milik pribadi masing-masing menjadi harta bersama, dapat pula ditetapkan tentang penggabungan hasil harta milik pribadi masing-masing suami istri dan dapat pula ditetapkan tidak adanya penggabungan milik pribadi masingmasing harta bersama suami istri. Jika dibuat perjanjian sebelum pernikahan dilaksanakan, maka perjanjian itu adalah sah dan harus dilaksanakan.

\section{Harta bersama menurut Peraturan}

\section{Perundang-undangan}

\section{Macam-macam harta keluarga}

Dalam perundang-undangan di Indonesia terdapat empat macam harta keluarga (gezimsgood) dalam perkawinan, yaitu:

a. Harta yang diperoleh dari warisan, baik sebelum mereka menjadi suami istri maupun setelah mereka melangsungkan perkawinan. Harta ini di Jawa Tengah disebut barang gawaan, di Betawi disebut barang usaha, di Banten disebut dengan barang sulur, di Aceh disebut harta tuha, atau harta pusaka, di Nganjuk Dayak disebut perimbit.

b. Harta yang diperoleh dengan keringat sendiri sebelum mereka menjadi suami istri. Harta yang demikian ini di Bali disebut guna kaya (lain dengan guna kaya di Sunda), di Sumatera Selatan dibedakan dengan harta milik suami dan harta milik istri sebelum kawin, kalau milik suami disebut harta pembujangan yang milik wanita/istri disebut harta penantian;

c. Harta dihasilkan bersama oleh suami istri selama berlangsungnya perkawinan. Harta semacam ini disebut harta 
Suarang (Minangkabau), Gonogini(Jawa Tengah dan Jawa Timur), Hareuta Sihareukat (Aceh), barang perpantangan (Kalimantan), Guna kaya (Jawa Barat), Druwe Gebru (Bali), Cakkar (Sulawesi Selatan), Ghumaghuma (Madura).

Harta yang didapat oleh pengantin pada waktu pernikahan dilaksanakan, harta ini menjadi milik suami istri selama perkawinan. (Abdul Manan, 2008: 106-107).

\section{Perluasan Makna Harta Bersama Perspektif Sosiologi Hukum Islam}

Perluasan berarti hal, hasil, cara atau proses kerja meluaskan. (Badudu, 1994: 829). Sedangkan Makna disebut juga dengan arti, maksud (Badudu, 1994: 848).

Dalam diskusi Hakim Tinggi Agama seluruh Indonesia yang diselenggarakan oleh Mahkamah Agung, seiring dengan perubahan sosial yang tengah terjadi di masyarakat maka kategori harta bersama (Abdul Manan, 2008: 12-128). Mengalami perluasan makna, di mana dibawah ini ada beberapa dana yang dapat dikategorikan sebagai harta bersama:

1. Dana Taspen

Taspen adalah Tabungan dan Asuransi Pegawai Negeri. Taspen termasuk kategori harta bersama karena asuransi premi Taspen tersebut diambil dari penghasilan suami istri setiap bulan. Meskipun dalam akad polis telah dicantumkan orang-orang tertentu sebagai penerima uang Taspen tersebut, tetapi hal ini hanya bersifat administrasi saja, dan menunjukkan itu hanya bersifat pemberian kuasa saja dalam menerima uang dari Taspen tersebut.

2. Dana Asabri

Dana Asabri adalah asuransi untuk Angkatan Bersenjata Republik Indonesia. Dana asabri disepakati sebagai harta bersama, karena premi yang disetorkan pada Asabri diambil dari gaji yang diperoleh suami atau istri setiap bulan.

3. Asuransi Tenaga Kerja (Astek)

Astek dapat dikategorikan ke dalam harta bersama suami istri karena perolehannya didasarkan perkongsian tenaga kerja dalam rumah tangga. Perkongsian ini dapat dikaitkan dengan syarikat 'abdan mereka (suami istri) masing-masing mengerjakan sesuatu pekerjaan dengan tenaga dan hasil untuk mereka bersama, dan bisa dikaitkan juga dengan syarikat muwaffadlah di mana mereka (suami istri) melakukan pekerjaan dengan tenaganya masing-masing, mereka mengeluarkan modal dan keuntungannya dinikmati bersama.

4. Dana Kecelakaan Lalu Lintas

Dana kecelakaan lalu lintas termasuk dalam kategori harta bersama karena undang-undang telah menentukan bahwa dana tersebut untuk mengurangi beban dari keluarga korban yang kena musibah itu. Dana tersebut diambil dari pengusaha/pemilik alat angkutan lalu lintas jalan yang diwajibkan untuk membayar setiap tahun, jadi pembayaran iuran wajib merupakan premi yang disetor oleh pemilik/pengusaha alat angkutan lalu 
lintas di waktu korban masih hidup. Pada hakikatnya adalah sama dengan pertanggungan yang lain, hanya teknisnya yang berbeda. Dijadikan harta bersama kalau yang kena musibah berupa kematian sudah dalam ikatan perkawinan yang sah, jika masih bujang/gadis tentu yang menerima sebagaimana yang diatur dalam Peraturan Pemerintah Nomor 18 Tahun 1965 diserahkan kepada orang tua si korban yang sah.

5. Dana Pertanggungan Wajib Kecelakaan Penumpang

Dana pertanggungan wajib kecelakaan penumpang termasuk dalam kategori harta bersama sebab premi yang disetor kepada PT Jasa Raharja yang kedudukannya sebagai penumpang adalah berasal dari iuran wajib yang dilekatkan pada tiket penumpang yang pembeliannya dilakukan ketika masih hidup. Penumpang yang telah mempunyai istri atau suami berhak menerima santunan tersebut yang dikategorikan sebagai harta bersama dalam perkawinan.

6. Dana Asuransi Jiwa

Dana asuransi jiwa termasuk kategori harta bersama, hal ini jika akad pertanggungan itu dilaksanakan dalam ikatan perkawinan dan angsuran premi setiap bulan diambil dari hasil yang didapat selama ikatan perkawinan itu berlangsung. Meskipun dalam polis asuransi itu telah ditunjuk orang-orang tertentu sebagai penerimaan dana pertanggungan tersebut, tetapi penunjukan itu hanya bersifat pemberi kuasa saja dalam menerima uang pertanggungan tersebut. Jika akad pertanggungan dilaksanakan sebelum pernikahan dilangsungkan, maka praktisi hukum harus memperhitungkan lebih dahulu uang pertanggungan tersebut sebagai uang tirkah sebab uang premi yang disetorkan merupakan uang premi yang disetorkan merupakan uang pribadi pihak suami, kemudian baru dihitung uang dana pertanggungan itu sebagai harta bersama sejak perkawinan dilaksanakan.

7. Harta dari Harta Bawaan

Harta hasil bawaan seperti keuntungan (hasil) dari deposito suami atau istri, sewa gedung atau rumah milik suami atau istri, hasil dari garapan atau budi daya tambaktambak ikan, dan sebagainya, dikategorikan sebagai harta bersama suami istri sepanjang tidak diperjanjikan secara tertulis sebelum perkawinan dilaksanakan. Jika telah diperjanjikan secara tertulis sebelum perkawinan dilaksanakan bahwa hasil harta bawaan itu tetap menjadi milik pribadi masing-masing, maka harta tersebut bukan harta bersama.

Harta bawaan ini menjadi harta bersama karena barang-barang tersebut didapat pada masa perkawinan, juga usaha-usaha yang menyangkut pengurusan dan pemeliharaan tersebut merupakan kegiatan dan pekerjaan yang dilakukan oleh suami atau istri di masa perkawinan 
berlangsung sebagaimana tersebut dalam Pasal 35 Ayat (2) Undangundang No. 1 Tahun 1974 tentang perkawinan.

8. Kredit yang Belum Lunas

Harta benda yang didapat melalui pembayaran angsuran kredit yang belum lunas seperti rumah tempat tinggal, kendaraan roda empat atau roda dua, rumah dan ruko atau barangbarang lain yang dibeli secara kredit yang pada saat perkawinan putus pembayarannya belum lunas, maka barang-barang tersebut termasuk dalam kategori harta bersama, karena yang dimaksud harta bersama itu termasuk aktiva dan pasiva, yaitu harta yang ada dan utang-utang yang belum dibayar.

Terhadap masalah ini, jika perkawinan putus karena perceraian maka pembagian harta bersama tersebut dapat melalui kompensasi berupa pengembalian oleh pihak yang ingin meneruskan kredit terhadap bagian pihak lain sesuai dengan jumlah kredit yang telah dilunasi atau melalui over kredit kepada pihak ketiga dan uang hasil overan tersebut dibagi kepada suami dan istri yang bermasalah itu.

\section{Contoh kasus penyelesaian harta bersama.}

1. Masalah Pembagian harta bersama sebelum dan sesudah ikrar talak dijatuhkan

Pada tanggal 10 Oktober 1992, seorang Dr. H. Ma'as Musa, umur 47 tahun, jabatan kepala Dinas
Pelayanan Medis Rumah Sakit Krakatau Steel di Cilegon mengajukan permohonan yang berisi: pertama tentang pengakuannya bahwa telah berlangsung pernikahan beliau dengan Ny. H. Eva Basyaruddin, umur, 41 tahun pada tanggal 20 Mei 1982. Dalam pernikahan tersebut belum dikaruniai anak, namun sudah mengangkat anak (adopsi) bernama Putri Sonia yang berumur satu setengah tahun. Bahwa semula rumah tangga mereka dalam keadaan rukun dan damai. Namun kemudian sejak tahun 1987 keadaan rumah tangga mereka mulai goyah, karena sejak itu sering terjadi perselisihan dan pertengkaran dan sudah tidak ada keharmonisan dan keserasian, karena termohon (istri) sudah tidak menghargai Pemohon sebagai suami. Pemohon dan termohon berumah tangga selama 10 tahun dan telah mempunyai harta bersama, namun untuk menyelesaikan masalah tersebut akan dilaksanakan setelah terjadinya perceraian nanti. Berdasarkan uraian di atas, Pemohon bermohon kepada Ketua Pengadilan Agama Serang agar memberikan keputusan menerima dan mengabulkan permohonan Pemohon seluruhnya serta mengizinkan kepada Pemohon untuk mengucapkan ikrar talak terhadap termohon.

Termohon melalui kuasanya memberikan jawaban yang pada 
pokoknya antara lain, menyangkal keras seluruh alasan-alasan Pemohon kecuali yang diakuinya adalah bahwa benar Termohon adalah istri Pemohon dan belum dikarunia anak namun telah mengangkat anak bernama Putri Sonia. Tidak benar bahwa antara Pemohon dan Termohon sering terjadi pertengkaran, yang ada hanyalah salah paham yang lazim terjadi di rumah tangga dan tidak sering atau dikatakan jarang. Namun, apabila terjadi perselisihan, Termohon lebih suka menghindar untuk mencegah terjadinya keributan dan berusaha memperbaiki suasana, dan tidak benar bahwa Termohon tidak menghargai Pemohon selaku suami. Bahwa secara tiba-tiba Pemohon memberitahukan ingin menceraikan Termohon pada keesokan harinya dan setidak-tidaknya sebelum empat puluh hari setibanya kami dari melakukan haji, hal mana sangat mengejutkan Termohon, karena sebelumnya tidak pernah ada masalah antara Pemohon dan Termohon. Adapun masalah belum dikarunia anak, maka hasil pemeriksaan medis menyimpulkan bahwa dr. Ma'as Musa yang kurang subur. Benar pada tanggal 22 Juni 1992 Pemohon telah meninggalkan rumah tetapi hingga kini Termohon tidak mengetahui sebabnya karena sepanjang pengetahuan Termohon tidak ada masalah dalam rumah tangga. Bahwa bila Majelis Hakim berpendapat perceraian tidak dapat dihindarkan lagi, maka Termohon menuntut agar Majelis Hakim berkenan menetapkan mengenai hak Termohon sebagai akibat hukum perceraian sesuai hukum berlaku, yaitu tentang uang iddah, uang mut'ah, dan pemisahan harta bersama yang didapat selama perkawinan.

Keputusan Pengadilan

Agama

Serang

No.339/PTS/92/93/PA.SRG yang menetapkan mengizinkan kepada Pemohon untuk mengucapkan ikrar talak terhadap Termohon (Ny. Eva Basyaruddin) di depan sidang Pengadilan Agama Serang pada waktunya.

Sedangkan permasalahan kedua yaitu mengenai hak istri (Termohon) sebagai akibat dari terjadinya perceraian, dan beberapa hal yang menyangkut dengan masalah harta bersama dilakukan pemisahan.

Merasa dirugikan, pihak Termohon (Ny. Eva Basyaruddin) menuntut masalah harta bersama harus sekaligus diselesaikan bersama, bukan secara terpisah. Pengadilan Agama Serang dalam putusannya No.339/PTS/92/93/ PA.SRG telah menetapkan menghukum dan memerintahkan kepada Tergugat (dr. Ma'as Musa) untuk membagi dan memberikan harta bersama 50\% bagian untuk Penggugat (Ny. Eva 
Basyaruddin) dan 50\% untuk Tergugat ( dr. Ma'as Musa) dari seluruh harta bersama. Putusan ini tidak diterima oleh pihak Tergugat (Pemohon yaitu dr. Ma'as Musa) dan setelah naik banding, putusan tersebut dibatalkan oleh Pengadilan Tinggi Agama Bandung dengan pertimbangan bahwa faktual "ikrar talak" oleh Tergugat dalam rekonvensi (dr. Ma'as Musa) terhadap Penggugat dalam rekonvensi (Ny. Eva Basyaruddin) belum diucapkan, maka secara hukum Agama, hak penggugat dalam rekonvensi tersebut belum saatnya sehingga harus dikesampingkan dan gugatan tersebut dapat diajukan tersendiri apabila perceraian/talaknya secara hukum telah jatuh, yakni setelah putusan/penetapan izin ikrar talaknya telah jatuh, yakni setelah putusan/penetapan izin ikrar talaknya telah mempunyai kekuatan hukum tetap dan sidang penyaksian ikrar talaknya telah dilakukan. Setelah pihak Penggugat dalam rekonvensi (Ny. Eva Basyaruddin) mengajukan permohonan kasasi, keputusan Pengadilan Tinggi Agama Bandung tersebut dibatalkan oleh Mahkamah Agung dalam putusannya No 41-K/AG/1994 dengan menetapkan menghukum dr. Ma'as Musa untuk membagi dan memberikan harta bersama 50\% bagian untuk Ny. Eva Basyaruddin, dan 50\% lagi untuk dr. Ma'as Musa sendiri. (Satria Effendi, 2010: 54-55).

2. Masalah Pembagian harta bersama tentang Dana Asuransi

Seorang Muslim yang bekerja di Perusahaan Caltex Pekanbaru meninggal dunia sewaktu dalam melaksanakan tugasnya. Oleh pihak perusahaan diserahkan uang Astek (Asuransi tenaga kerja) sebesar $\mathrm{Rp}$ 20.000.000,- (dua puluh juta rupiah). Uang Astek tersebut dikuasai oleh istri almarhum dan sedikitpun tidak ada yang diberikan kepada ahli waris almarhum. Oleh karena itu ayah almarhum merasa juga berhak atas harta yang diperoleh dari Astek itu, maka ia menggungat istri almarhum ke Pengadilan Agama Pekanbaru dengan tuntutan agar harta dari Astek tersebut dibagi kepada semua ahli waris sebagai harta tirkah. Terhadap gugatan ini, Pengadilan Agama Pekanbaru menetapkan bahwa uang Astek yang sekarang dikuasai oleh istri almarhum termasuk harta tirkah dan bukan harta bersama. Oleh karena itu, semua dana dari Astek tersebut dibagi kepada seluruh ahli waris.

Dalam diskusi Hakim Tinggi Pengadilan Tinggi Agama seluruh Indonesia angkatan pertama ketika mengikuti pelatihan Teknis Yustisial Mahkamah Agung RI Tahun 1995 di Bandung disimpulkan bahwa dana asuransi tenaga kerja (Astek) dapat dikategorikan ke dalam harta bersama suami istri karena perolehannya didasarkan 
perkongsian tenaga kerja dalam rumah tangga. Pengkongsian disini dapat dikaitkan dengan syarikat abdan mereka (suami istri) masingmasing mengerjakan sesuatu pekerjaan dengan tenaga dan hasil untuk mereka bersama, dan bisa dikaitkan juga dengan syarikat muwafadlah di mana mereka (suami istri) melakukan pekerjaan dengan tenaganya masing-masing, mereka mengeluarkan modal dan keuntungannya dinikmati bersama. (Satria Effendi, 2010: 118-119).

\section{Hal-hal yang mempengaruhi Perubahan Harta Bersama dalam perspektif Sosiologi Hukum Islam}

1. Perubahan Peran Suami dan Peran Istri.

Berdasarkan Pasal 96 KHI dan Pasal 37 Undang-undang Perkawinan dikemukakan bahwa harta bersama suami istri apabila terjadi putusnya perkawinan baik karena kematian atau perceraian maka kepada suami istri tersebut masing-masing mendapat setengah bagian dari harta yang mereka peroleh selama perkawinan berlangsung. Ketentuan ini adalah sejalan putusan Mahkamah Agung RI tanggal 9 Desember 1959 No.424.K/SIP/1959, dimana dalam putusan tersebut dinyatakan bahwa harta suami istri kalau terjadi perceraian maka masing-masing pihak mendapat setengah bagian.

Sehubungan dengan hal tersebut pembagian harta bersama setengah untuk suami dan setengah untuk istri dalam kasus-kasus tertentu dapat dilenturkan, mengingat realita dalam kehidupan keluarga di beberapa daerah Indonesia ini ada pihak suami yang tidak berpartisipasi dalam membangun ekonomi rumah tangga. Dalam hal ini, sebaiknya para praktisi hukum lebih berhati-hati dalam memeriksa kasuskasus tersebut agar memenuhi rasa keadilan, kewajaran, dan kepatutan. Oleh karena itu perlu adanya keluarga, sehingga bagian yang menetapkan setengah dari harta bersama untuk suami perlu dilenturkan lagi sebagaimana yang diharapkan oleh Pasal 229 KHI "Hakim dalam menyelesaikan perkara-perkara yang diajukan kepadanya wajib memperhatikan dengan sungguh-sungguh nilai-nilai hukum yang hidup dalam masyarakat sehingga putusannya sesuai dengan rasa keadilan."

2. Adanya Perjanjian dalam Perkawinan

Bahasan tentang syarat dalam perkawinan tidak sama dengan syarat perkawinan yang dibicarakan dalam semua kitab fiqh karena yang dibahas dalam syarat perkawinan itu adalah syarat-syarat untuk sahnya suatu perkawinan, yang materinya telah lebih dahulu dibahas.

Kaitan antara syarat dalam perkawinan dengan perjanjian dalam perkawinan adalah karena perjanjian itu berisi syarat-syarat yang harus dipenuhi oleh pihak yang melakukan perjanjian dalam arti pihak-pihak yang berjanji untuk memenuhi syarat yang ditentukan. Namun perjanjian itu tidak 
sama dengan sumpah, yaitu : wallahi, billahi, dan tallahi, dan membawa akibat dosa bagi yang tidak memenuhinya ( Amir Syarifuddin, 2007: 145)

Membuat Perjanjian dalam perkawinan hukumnya adalah mubah, artinya boleh seseorang untuk membuat perjanjian dan boleh pula tidak membuat. Namun kalau sudah dibuat bagaimana hukum memenuhi syarat yang terdapat dalam perjanjian perkawinan itu, menjadi perbincangan di kalangan ulama. Jumhur ulama berpendapat bahwa memenuhi syarat yang dinyatakan dalam bentuk perjanjian itu hukumnya adalah wajib sebagaimana hukum memenuhi perjanjian lainnya; bahkan syarat-syarat yang berkaitan dengan perkawinan lebih berhak untuk dilaksanakan. Hal ini ditegaskan dalam hadis Nabi dari 'Uqbah bin 'Amir menurut jema'ah ahli hadis:

$$
\text { أحق الشروط با لوفاء مااستحللتم به الفروج }
$$

Syarat-syarat yang paling layak untuk dipenuhi adalah syarat yang berkenaan dengan perkawinan.

Al-Syaukani menambahkan alasan lebih layaknya memenuhi persyaratan yang berkenaan dengan perkawinan itu adalah karena urusan perkawinan itu sesuatu yang menuntut kehati-hatian dan pintu masuknya sangat sempit. (AlSyaukaniy, 1973: 280). Kewajiban memenuhi persyaratan yang terdapat dalam perjanjian dan terikatnya dengan kelangsungan perkawinan tergantung kepada bentuk persyaratan yang ada dalam perjanjian. Dalam hal ini ulama membagi syarat itu menjadi tiga:

a. Syarat-syarat yang langsung berkaitan dengan pelaksanaan kewajiban suami istri dalam perkawinan dan merupakan tuntutan dari perkawinan itu sendiri. Umpamanya, suami istri bergaul secara baik, suami mesti memberi nafkah untuk anak dan istrinya; istri mesti melayani kebutuhan seksual suaminya dan suami istri memelihara anak yang lahir dari perkawinan itu.

b. Syarat-syarat yang bertentangan dengan hakikat perkawinan atau yang secara khusus dilarang untuk dilakukan atau memberi mudarat kepada pihak-pihak tertentu. Umpamanya, suami atau istri mempersyaratkan tidak akan beranak; istri mempersyaratkan suami menceraikan istri-istrinya yang lebih dahulu; suami mempersyaratkan dia tidak akan membayar mahar atau nafkah dan suami meminta istrinya mencari nafkah secara tidak halal, seperti pelacur.

c. Syarat-syarat yang tidak menyalahi tuntutan perkawinan dan tidak ada larangan secara khusus namun tidak ada tuntunan dari syara' untuk dilakukan. Umpamanya, istri mempersyaratkan bahwa suaminya tidak akan memadunya, hasil pencarian dalam rumah tangga menjadi milik bersama (Amir Syarifuddin, 2007: 147) 
Ulama sepakat mengatakan bahwa syarat-syarat dalam bentuk pertama wajib dilaksanakan. Mereka mengatakan hadis Nabi yang disebutkan di atas mengarah kepada syarat-syarat dalam bentuk pertama ini. Pihak yang terlibat atau yang berjanji wajib memenuhinya. Pihak yang berjanji terikat dengan persyaratan tersebut. Namun bila pihak yang berjanji tidak memenuhi persyaratan tersebut tidak menyebabkan perkawinan dengan sendirinya batal, risiko dari tidak memenuhi persyaratan ini ialah adanya hak bagi pihak yang dirugikan untuk menuntut suaminya di pengadilan untuk batalnya perkawinan.

Seseorang yang tidak membayar nafkah sesuai dengan yang dijanjikan namun istri menerima keadaan tersebut, orang lain tidak berhak membatalkan perkawinan itu. Tetapi bila istri dirugikan, tidak rela, ia berhak menuntut pembatalan perkawinan dengan alasan tidak memenuhi janji.

Dalam hal syarat bentuk kedua sepakat ulama mengatakan bahwa perjanjian itu tidak wajib dipenuhi dalam arti tidak berdosa orang yang melanggar perjanjian, meskipun menepati perjanjian itu menurut asalnya diperintahkan. Kebolehan melanggar perjanjian ini jika dalam syarat perjanjian tersebut bertentangan dengan hukum syara' . hadis Nabi yang dikeluarkan oleh alThabraniy mengatakan:

$$
\text { حلا لالمسون عند شروطهم الا شر طا أحل حرا ما أو حرم }
$$

Orang Islam itu harus memenuhi syarat mereka kecuali syarat yang menghalalkan yang haram atau mengharamkan yang halal.

Adapun perjanjian dalam bentuk persyaratan bentuk ketiga terdapat perbedaan pendapat di kalangan ulama. Dalam contoh, istri meminta supaya dia tidak dimadu, jumhur ulama diantaranya ulama Syafi'iyah berpendapat bahwa syarat tersebut tidak boleh dipenuhi, namun tidak membatalkan akad perkawinan kalau dilakukan. Alasan mereka ialah bahwa yang demikian termasuk syarat yang mengharamkan sesuatu yang halal sebagaimana tersebut dalam hadits Nabi di atas dan juga tidak termasuk ke dalam apa yang diatur dalam kitab Allah yang disebutkan dalam hadis itu.

Yang berbeda pendapat dengan jumhur dalam hal ini adalah ulama Hanabilah yang mengatakan bila istri mensyaratkan bahwa ia tidak dimadu wajib dipenuhi. Bagi mereka persyaratan ini telah memenuhi apa yang dikatakan Nabi tentang syarat yang paling layak untuk dipenuhi tersebut di atas. Disamping itu tidak terdapat larangan Nabi secara khusus untuk hal tersebut. Pendapat Imam Ahmad dalam hal ini sangat relevan dengan usaha memperkecil terjadinya poligami yang tidak bertanggungjawab(Ibnu Qudamah, 1970: 93).

Berdasarkan pendapat Ahmad atau Hanabilah tersebut terbukalah kesempatan untuk membuat persyaratan atau perjanjian dalam perkawinan selama 
tidak ditemukan secara khusus larangan Nabi untuk itu, seperti taklik talak dan adanya harta bersama dalam perkawinan meskipun keberadaan harta itu tidak ditemukan dalam kitab fiqh klasik. Alasannya ialah meskipun menurut kebiasaannya harta perkawinan itu di tangan suami, namun secara khusus tidak ada larangan untuk menggabungkan harta perkawinan itu.

Perjanjian dalam perkawinan mendapat tempat yang luas dalam UU Perkawinan, sebagaimana dijelaskan dalam Bab V Pasal 29 Undang-undang Nomor 1 Tahun 1974 yang bunyi selengkapnya sebagai berikut:

a. Pada waktu atau sebelum perkawinan dilangsungkan, kedua belah pihak atas persetujuan bersama dapat mengadakan perjanjian tertulis yang disahkan oleh Pegawai Pencatat Perkawinan, setelah mana isinya berlaku juga terhadap pihak ketiga sepanjang pihak ketiga tersebut tersangkut.

b. Perjanjian tersebut tidak dapat disahkan bilamana melanggar batasbatas hukum, agama, dan kesusilaan.

c. Perjanjian tersebut berlaku sejak perkawinan dilangsungkan.

d. Selama perkawinan berlangsung perjanjian tersebut tidak dapat diubah, kecuali bila kdari kedua belah pihak ada persetujuan untuk mengubah dan perubahan tidak merugikan pihak ketiga.

Penjelasan Pasal 29 tersebut menyatakan bahwa perjanjian dalam pasal ini tidak termasuk taklik talak. Namun dalam Peraturan Menteri Agama
Nomor 3 Tahun 1975 Pasal 11 disebutkan satu aturan yang bertolak belakang.

a. Calon suami istri dapat mengadakan perjanjian sepanjang tidak bertentangan dengan hukum Islam.

b. Perjanjian yang berupa taklik talak dianggap sah kalau perjanjian itu diucapkan dan ditandatangani oleh suami setelah akad nikah dilangsungkan.

c. Sighat taklik talak ditentukan oleh Menteri Agama.

Yang menarik adalah, kompilasi menggarisbawahi Pasal 11 Peraturan Menteri Agama tersebut, Kompilasi sendiri memuat delapan pasal tentang perjanjian perkawinan, yaitu pasal 45 sampai dengan Pasal 52.

Pasal 45 menyatakan:

Kedua calon mempelai dapat mengadakan perjanjian perkawinan dalam bentuk:

a. Taklik talak, dan

b. perjanjian lain yang tidak bertentangan dengan hukum Islam.

Jadi, perjanjian perkawinan seperti ditegaskan dalam penjelasan Pasal 29 Undang-undang No.1 Tahun 1974, telah diubah, atau setidaknya, diterapkan bahwa taklik talak termasuk salah satu macam perjanjian perkawinan.

Pasal 46 KHI lebih jauh mengatur ketentuan sebagai berikut:

a. Isi taklik talak tidak boleh bertentangan dengan hukum Islam.

b. Apabila keadaan yang diisyaratkan dalam taklik talak betul-betul terjadi kemudian, tidak dengan sendirinya talak jatuh. Supa talak sungguh- 
sungguh jatuh, istri harus mengajukan persoalannya ke Pengadilan Agama.

c. Perjanjian taklik talak bukan salah satu yang wajib diadakan pada setiap perkawinan, akan tetapi sekali taklik talak sudah diperjanjikan tidak dapat dicabut kembali.

Ayat (3) di atas sepintas bertentangan dengan pasal 29 Undangundang Perkawinan ayat (4) yang mengatur bahwa selama perkawinan berlangsung perjanjian tidak dapat diubah kecuali ada persetujuan kedua belah pihak, dan tidak merugikan pihak ketiga. Dari sinilah, dalam penjelasannya disebutkan tidak termasuk taklik talak, dilampirkan dalam salinan akta nikah yang sudah ditanda tangani suami. Oleh karena itu pula, perjanjian taklik talak sekali sudah diperjanjikan tidak dapat dicabut kembali.

Sebelum akad nikah dilangsungkan, Pegawai Pencatat perlu meneliti betul perjanjian perkawinan yang dibuat oleh kedua calon mempelai, baik secara material atau isi perjanjian itu, maupun teknis bagaimana perjanjian itu telah disepakati mereka bersama. Sejauh perjanjian itu berupa taklik talak, Menteri Agama telah mengaturnya. Adapun teks (sighat) taklik talak yang diucapkan suami sesudah dilangsungkan akad nikah adalah sebagai berikut:

$$
\begin{aligned}
& \text { "Sesudah akad nikah, } \\
& \text { saya......bin......berjanji dengan } \\
& \text { sesungguh hati, bahwa saya akan } \\
& \text { menepati kewajiban saya sebagai } \\
& \text { seorang suami, dan akan saya pergauli } \\
& \text { istri saya bernama...binti....dengan baik }
\end{aligned}
$$

(mu'syarah bil ma'ruf) menurut ajaran syari'at Islam.

Selanjutnya saya mengucapkan sighat taklik talak atas istri saya itu sebagai berikut:

$$
\text { Sewaktu-waktu saya: }
$$

a. Meninggalkan istri saya tersebut dua tahun berturut turut,

b. Atau saya tidak memberi nafkah wajib kepadanya tiga bulan lamanya,

c. Atau saya menyakiti badan/jasmani istri saya itu,

d. Atau saya membiarkan (tidak memedulikan) istri saya itu enam bulan lamanya.

Kemudian istri saya tidak ridha dan mengadukan halnya kepada Pengadilan Agama atau petugas yang diberi hak mengurus pengaduan itu, dan pengaduannya dibenarkan serta diterima oleh pengadilan atau petugas tersebut, dan istri saya itu membayar uang sebesar Rp 1.000,(seribu rupiah) sebagai 'iwadl (pengganti) kepada saya, maka jatuhlah talak saya satu kepadanya. Kepada pengadilan atau petugas tersebut tadi saya kuasakan untuk menerima uang 'iwadl (pengganti) itu dan kemudian memberikannya untuk keperluan ibadah sosial.

(Tempat, tanggal, Bulan dan Tahun)

Suami 
(Tanda tangan dan Nama)"

Secara teknis Pegawai Pencatat perlu memeriksa secara teliti, sebagaimana disebut dalam Pasal 26 Peraturan Menteri Agama Nomor 3 Tahun 1975:

a. Apabila pada waktu pemeriksaan nikah calon suami istri telah menyetujui adanya taklik talak sebagai dimaksudkan Pasal 11 ayat (3) peraturan ini, maka suami mengucapkan dan menandatangani taklik talak yang telah disetujuinya itu setelah akad nikah dilangsungkan.

b. Apabila dalam pemeriksaan nikah telah ada persetujuan adanya taklik talak akan tetapi setelah akad nikah suami tidak mau mengucapkannya maka hal ini segera diberitahukan kepada pihak istrinya.

Memerhatikan muatan sighat taklik talak tersebut, kandungan maksudnya cukup baik dan positif, yaitu melindungi perempuan dari kesewenang-wenangan suami dalam memenuhi kewajibannya, sebagai hak-hak yang seharusnya diterima si istri. Meskipun sesungguhnya istri, telah mendapat hak berupa khulu' (gugat cerai) maupun hak fasakh. Karena itu, yang perlu diperhatikan adalah pencatatan apakah suami benar-benar menyetujui dan membaca dan menandatangani sighat taklik talak tersebut atau tidak. Ini dimaksudkan agar tidak terjadi kekeliruan dan kesulitan dalam menyelesaikan persoalan yang timbul (Ahmad Rofiq, 2013: 133).
Perjanjian perkawinan juga dapat dibuat oleh kedua belah pihak menyangkut harta bersama dan hal-hal lain sepanjang tidak bertentangan dengan aturan syari' at Islam. Kompilasi mengatur perjanjian harta bersama dan perjanjian yang berkaitan dengan masalah poligami:

Pasal 47

a. Pada waktu atau sebelum perkawinan dilangsungkan kedua calon mempelai dapat membuat perjanjian tertulis yang disahkan Pegawai Pencatat Nikah mengenai kedudukan harta dalam perkawinan.

b. Perjanjian tersebut dalam ayat (1) dapat meliputi percampuran harta pribadi dan pemisahan harta pencaharian masing-masing sepanjang hal itu tidak bertentangan dengan syari'at Islam.

c. Di samping ketentuan dalam ayat (1) dan (2) di atas, boleh juga isi perjanjian itu menetapkan kewenangan masingmasing untuk mengadakan ikatan hipotik atas harta pribadi dan harta bersama atau harta syarikat.

Pasal 48

a. Apabila dibuat perjanjian perkawinan mengenai pemisahan harta bersama atau harta syarikat, maka perjanjian tersebut tidak boleh menghilangkan kewajiban suami untuk memenuhi kebutuhan rumah tangga.

b. Apabila dibuat perjanjian perkawinan tidak memenuhi ketentuan tersebut pada ayat (1) dianggap tetap terjadi pemisahan harta bersama atau harta syarikat dengan kewajiban suami menanggung biaya kebutuhan rumah tangga. 


\section{Pasal 49}

a. Perjanjian percampuran harta pribadi dapat meliputi semua harta, baik yang dibawa masing-masing ke dalam perkawinan maupun yang diperoleh masing-masing selama perkawinan.

b. Dengan tidak mengurangi ketentuan tersebut pada ayat (1) dapat juga diperjanjikan bahwa percampuran harta pribadi yang dibawa pada saat perkawinan dilangsungkan, sehingga percampuran ini tidak meliputi harta pribadi yang diperoleh selama perkawinan atau sebaliknya.

\section{Pasal 50}

a. Perjanjian perkawinan mengenai harta, mengikat kepada para pihak dan pihak ketiga terhitung mulai tanggal dilangsungkan perkawinan di hadapan Pegawai Pencatat Nikah.

b. Perjanjian perkawinan mengenai harta dapat dicabut atas persetujuan bersama suami-istri dan wajib mendaftarkannya di Kantor Pegawai Pencatat Nikah tempat perkawinan dilangsungkan.

c. Sejak pendaftaran tersebut, pencabutan telah mengikat kepada suami-istri tetapi terhadap pihak ketiga, pencabutan baru mengikat sejak tanggal pendaftaran itu diumumkan suami-istri dalam suatu surat kabar setempat.

d. Apabila dalam tempo 6 (enam) bulan pengumuman tidak dilakukan yang bersangkutan, pendaftaran pencabutan dengan sendirinya gugur dan tidak mengikat kepada pihak ketiga.

e. Pencabutan perjanjian perkawinan mengenai harta tidak boleh merugikan perjanjian yang telah diperbuat sebelumnya dengan pihak ketiga.

\section{Pasal 51}

Pelanggaran atas perjanjian perkawinan memberi hak kepada istri untuk meminta pembatalan nikah atau mengajukannya. Sebagai alasan gugatan perceraian ke Pengadilan Agama.

\section{Pasal 52}

Pada saat dilangsungkan perkawinan dengan istri kedua, ketiga dan keempat, boleh diperjanjikan mengenai tempat kediaman, waktu giliran dan biaya rumah tangga bagi istri yang akan dinikahinya itu.

$$
\text { Pada saat dilangsungkan }
$$
perkawinan dengan istri kedua, ketiga dan keempat, boleh diperjanjikan mengenai tempat kediaman, waktu giliran, dan biaya rumah tangga bagi istri yang akan dinikahinya itu.

\section{Pengaruh Perjanjian dalam Perkawinan terhadap Pembagian Harta bersama}

Perjanjian dalam perkawinan jika dikaitkan dengan harta bersama terlihat mempunyai pengaruh. Menurut konsep fiqih bahwa ketika perjanjian sudah di buat, maka secara otomatis pembagian harta bersama sudah tidak dapat diganggu gugat sesuai dengan isi kesepakatan dalam perkawinan baik sebelum atau setelah perkawinan.

Adanya pengaruh perjanjian dalam perkawinan terhadap pembagian harta bersama disebabkan karena adanya ketentuan yang terdapat dalam:
a. Pasal 45 KHI menyebutkan bahwasanya dibolehkan mengadakan 
perjanjian perkawinan dalam bentuk: Taklik talak, dan Perjanjian lain yang tidak bertentangan dengan hukumIslam.

b. Pasal 52 KHI juga menyebuutkan Pada saat dilangsungkan perkawinan dengan istri kedua, ketiga dan keempat, boleh diperjanjikan mengenai tempat kediaman, waktu giliran dan biaya rumah tangga bagi istri yang akan dinikahinya itu.

c. Pasal $97 \mathrm{KHI}$ “ janda atau duda cerai masing-masing berhak seperdua harta bersama sepanjang tidak ditentukan lain dalam perjanjian perkawinan.

\section{KESIMPULAN}

1. Dalam hal terjadinya perceraian karena situasi masih dalam masa iddah talak raj'i, harta sebaiknya tidak dibagi karena memperkecil kemungkinan bersatu kembali. Berbeda halnya jika talak ba'in, harta bersama layak ditentukan pembagiannya karena sudah pasti tidak akan bersatu kembali.

2. Harta bersama mengalami perluasan disebabkan adanya perubahan sosial seperti asuransi Taspen, Dana Asabri, Asuransi Tenaga Kerja, Dana Kecelakaan Lalu lintas, Dana Pertanggungan Kecelakaan Penumpang, Dana Asuransi Jiwa, Harta dari Harta bawaan, Kredit yang belum lunas.

3. Harta bersama mempunyai hubungan dengan adanya perjanjian dalam perkawinan. Sesuai dengan penjelasan Pasal 45, 52, dan 97 Kompilasi Hukum Islam " janda atau duda cerai masingmasing berhak seperdua harta bersama sepanjang tidak ditentukan lain dalam perjanjian perkawinan.

4. Pembagian harta bersama setelah perceraian atau kematian dengan bagian seperdua masih bisa mengalami perubahan disebabkan adanya perubahan peran suami dan istri. Jika istri lebih dominan dalam perannya untuk menghidupi keluarga, agar memenuhi rasa keadilan, kewajaran, dan kepatutan bagian yang menetapkan setengah dari harta bersama untuk suami perlu dilenturkan lagi sebagaimana yang diharapkan oleh Pasal 229 KHI "Hakim dalam menyelesaikan perkara-perkara yang diajukan kepadanya wajib memperhatikan dengan sungguh-sungguh nilai-nilai hukum yang hidup dalam masyarakat sehingga putusannya sesuai dengan rasa keadilan."

\section{DAFTAR KEPUSTAKAAN}

Abdul Manan, Aneka Masalah Hukum Perdata Islam di Indonesia, Jakarta: Kencana, 2008

Abdul Basith Junaidy, Harta Bersama dalam Hukum Islam di Indonesia, Jurnal AlQânûn, Vol 17, No. 2, Desember 2014 Ahmad Rofiq, Hukum Perdata Islam di Indonesia, Jakarta: PT. Rajawali Pers, 2013

Al-Hafidz Ibnu Katsir Ad-dimasyqy, Tafsir Ibnu Katsir, Beirut; Darul Kutub Ilmiyah, 2006

Al-Syaukaniy, Muhammad bin ali, Nayl alAuthar, Beirut: Dar al-Jail, 1973

Amir Syarifuddin, Hukum Perkawinan Islam di Indonesia, Antara Figh Munakahat dan Undang-Undang Perkawinan, Jakarta: Kencana, 2007 
Badudu, Kamus Umum Bahasa Indonesia, Jakarta: Pustaka Sinar Harapan, 1994 Effendi, Satria Effendi, Problematika Hukum Keluarga Islam Kontemporer, AnalisisYurisprudensi dengan Pendekatan Ushuliyah, Jakarta: Kencana, 2010

Fathurrahman Djamil, Hukum Ekonomi Islam, Sejarah, teori dan Konsep, Jakarta: Sinar Grafika, 2013.

Ibnu Qudamah, al-Mughny, Cairo: Musthafa al-Babiy al-Halaby, 1970
M. NYahya Harahap, Kedudukan Kewenangan dan Acara Peradilan Agama, Jakarta: Sinar Grafika, 2005

M. Rayid Ridla, Sosiologi Hukum Islam (Analisis terhadap Pemikiran M. Atho' Mudzhar), Jurnal al-Ihkam Vol. 7 No.2 Desember 2012

Quraish Shihab, M. 2009, Tafsir al-Mishbah Pesan, Kesan dan keserasian al-Qur'an, Jakarta: Lentera Hati.

Tim Redaksi Nuansa Aulia, Kompilasi Hukum Islam, Bandung: Nuansa Aulia, 2011. 